\title{
Breast Abscess and Staphylococcal Disease in a Maternity Hospital
}

\author{
V. D. PLUECKHAHN,* M.D., M.R.A.C.P., M.C.P.A., M.C.PATH. ; JOAN BANKS,* B.SC.
}

Brit. med. F., 1964, 2, 414-418

This report concerns the occurrence of breast abscess in 18,275 mothers delivered in the 95-bed maternity unit of the Geelong and District Hospital between July 1956 and December 1963. A reduction in the incidence of puerperal breast abscess from $2.5 \%$ to $0.16 \%$ of mothers delivered during this time is reported and factors responsible are discussed.

Geelong is a rural industrial city of approximately 100,000 inhabitants. The city and surrounding district are well defined and depend on the Geelong and District Hospital for all maternity beds and more than $90 \%$ of general-hospital beds. This centralization of medical services greatly facilitated an almost complete follow-up investigation of mothers and babies for a period of six months after delivery. In addition, all medical practitioners in the area co-operated fully in this survey by making their private records available and completing questionaries circulated to them at three-monthly intervals. Further information was gained by checking private and public hospital records, the records of infant health centres, and by personal contact of mothers after discharge home by visits, telephone, or posted questionaries.

The term "puerperal breast abscess" is used to denote any inflammatory condition, of either breast, which occurred within six months of delivery, and which resulted in suppuration or required incision. Staphylococcal skin disease includes pustules, paronychia, abscesses, rashes, and any other skin lesions from which staphylococci were grown on culture.

Minimal observer variation has occurred during the survey. All aspects have been continually supervised by one or other of us. Three of the four floors in the maternity wing have had the same sister-in-charge throughout the survey.

Many other aspects of this study, including basic nursery techniques and bacteriological methods used, have been reported in previous papers (Plueckhahn, 1961; Plueckhahn and Banks, 1958, 1961, 1963). Any reference to the staphylococcus refers to a coagulase-positive Staphylococcus aureus unless otherwise stated.

\section{Results}

The results of certain aspects of this survey are shown in Tables I to XII.

Breast Abscess-Type and Bacterial Agent Responsible.Table I records the total number of breast abscesses occurring in Geelong from 1 July 1956 to 31 December 1963. It shows that $96 \%$ of these abscesses were directly related to pregnancy and that a coagulase-positive Staph. aureus was the bacterial agent responsible in every breast abscess from which material was available for culture.

Puerperal Breast Abscess-Incidence in 18,275 Mothers Delivered during fuly 1956 to December 1963.-Table II shows the incidence and number of breast abscesses developing each year. The corresponding yearly incidence of staphylococcal skin disease in infants up to 10 days old is also shown. The marked reduction in infant staphylococcal skin disease and the corresponding decrease in puerperal breast abscess occurring during the survey is clearly shown in Table II.

- From the Department of Pathology, Geelong and District Hospltal, Geelong, Victoria, Australia.
Antiseptic Skin Care of Infants and Incidence of Puerperal Breast Abscess in Mothers.-From January 1960 all infants nursed on two floors of the maternity wing underwent skin care with Phisohex. A similar emulsion but not containing hexachlorophane was used on the infants nursed on the other two floors. The emulsions were applied over the entire body surface of the baby at birth and thereafter on alternate days (Plueckhahn, 1961). The type of emulsion used on the respective floors was alternated at intervals of three months. There was a marked reduction in the incidence of staphylococcal infection and skin disease in the infants undergoing antiseptic skin care with Phisohex. In October $19613 \%$ hexachlorophane was added to the non-antiseptic emulsion, and this emulsion or Phisohex was then used on all infants delivered in the maternity wing (Plueckhahn and Banks, 1963). Table III shows the incidence of breast abscess developing in those mothers whose infants had antiseptic skin care and compares this with the incidence in mothers whose infants were not treated with a $3 \%$ hexachlorophane emulsion. The incidence of staphylococcal skin disease in both groups of infants is also shown. Table III

TABLE I.-Distribution and Bacterial Agent Responsible for Breast Abscesses Occurring in Geelong from 1 fuly 1956 to 31 December 1963

\begin{tabular}{|c|c|c|c|c|c|}
\hline \multicolumn{3}{|c|}{ Type of Breast Abscess } & No. & Cultures & $\begin{array}{l}\text { Staph. } \\
\text { aureus }\end{array}$ \\
\hline 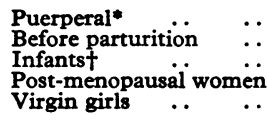 & $\begin{array}{l}\ddot{.} \\
\ddot{*} \\
\cdots\end{array}$ & $\begin{array}{l}\ldots \\
\ddot{*} \\
\ddot{*}\end{array}$ & $\begin{array}{r}149 \\
2 \\
5 \\
4 \\
2\end{array}$ & $\begin{array}{r}67 \\
2 \\
5 \\
4 \\
2\end{array}$ & $\begin{array}{r}67 \\
2 \\
5 \\
4 \\
2\end{array}$ \\
\hline & & & 162 & 80 & 80 \\
\hline
\end{tabular}

* 142 women. Bilateral breast abscess in seven cases.

t Three males and two females. Abscesses occurred within four weeks of delivery.

TABLE II.-Puerperal Breast Abscess Developing in Mothers and Incidence of Staphylococcal Skin Disease Occurring in Infants Delivered in Geelong from fuly 1956 to December 1963

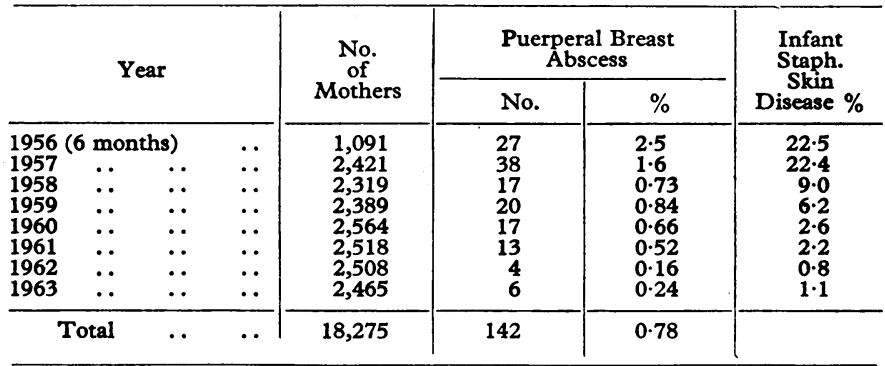

TABLE III.-Incidence of Breast Abscess in Mothers Nursing Infants Treated with a 3\% Hexachlorophane Emulsion Compared with that in Mothers Where Infant Antiseptic Skin Care was Not Used. The Incidence of Staphylococcal Skin Disease Occurring in Each Group Incidence of Staphylococcal
of Infants is Also Shown

\begin{tabular}{|c|c|c|c|c|c|c|}
\hline \multirow[b]{2}{*}{ Year } & \multicolumn{3}{|c|}{$\begin{array}{c}\text { No Antiseptic Skin Care } \\
\text { of Infants }\end{array}$} & \multicolumn{3}{|c|}{$\begin{array}{c}\text { Antiseptic Skin Care } \\
\text { of Infants }\end{array}$} \\
\hline & $\begin{array}{c}\text { No. } \\
\text { of } \\
\text { Mothers }\end{array}$ & $\begin{array}{c}\text { Incidence } \\
\text { of } \\
\text { Breast } \\
\text { Abscess } \\
\%\end{array}$ & $\begin{array}{c}\text { Infant } \\
\text { Staph. } \\
\text { Skin } \\
\text { Disease } \\
\%\end{array}$ & $\begin{array}{c}\text { No. } \\
\text { of } \\
\text { Mothers }\end{array}$ & $\begin{array}{c}\text { Incidence } \\
\text { of } \\
\text { Breast } \\
\text { Abscess } \\
\%\end{array}$ & $\begin{array}{c}\text { Infant } \\
\text { Staph. } \\
\text { Skin } \\
\text { Disease } \\
\%\end{array}$ \\
\hline $\begin{array}{l}1960 \\
1961 \\
1962 \\
1963\end{array}$ & $\begin{array}{r}1,299 \\
927\end{array}$ & $\begin{array}{l}0.85 \\
0.97\end{array}$ & $\begin{array}{l}3 \cdot 4 \\
4 \cdot 3\end{array}$ & $\begin{array}{l}1,265 \\
1,591 \\
2,508 \\
2,465\end{array}$ & $\begin{array}{l}0.48 \\
0.25 \\
0.16 \\
0.24\end{array}$ & $\begin{array}{l}1 \cdot 2 \\
0.70 \\
0.83 \\
1 \cdot 1\end{array}$ \\
\hline
\end{tabular}


clearly shows the marked decrease in incidence of breast abscess occurring in mothers nursing infants undergoing antiseptic skin care with a $3 \%$ hexachlorophane emulsion.

Puerperal Breast Abscess-Time of Onset Following Parturition.-Seven women developed an abscess in each breast. Five of these bilateral abscesses developed quite independently of each other. In one case there was an interval of three months between the development of each abscess. There was thus a total of 149 breast abscesses occurring in 142 women after delivery. The exact date of development and incision of five abscesses occurring in 1956 was not available, and Table IV shows the time of onset after parturition of the remaining 144 breast abscesses.

Table IV.-Time of Onset, After Parturition, of 144 Breast Abscesses Occurring in Geelong During 1956-63

\begin{tabular}{|c|c|c|c|c|c|c|c|c|}
\hline \multirow{2}{*}{\multicolumn{7}{|c|}{ Interval after Parturition (Days) }} & \multicolumn{2}{|c|}{ Puerperal Breast Abscess } \\
\hline & & & & & & & No. & $\%$ \\
\hline $\begin{array}{l}<14 \\
14-28 \\
29-60 \\
60-120 \\
120-180 \\
>180\end{array}$ & $\begin{array}{l}\ldots \\
\cdots \\
\cdots \\
\cdots\end{array}$ & $\begin{array}{l}\because \\
\cdots \\
\cdots \\
\cdots\end{array}$ & $\begin{array}{l}\because \\
\because \\
\because \\
\cdots\end{array}$ & $\begin{array}{l}\because \\
\cdots \\
\cdots \\
\cdots\end{array}$ & $\begin{array}{c}\because \\
\because \\
\because \\
\because\end{array}$ & $\begin{array}{l}\because \\
\because \\
\cdots \\
\cdots\end{array}$ & $\begin{array}{r}8 \\
63 \\
55 \\
13 \\
3 \\
2\end{array}$ & $\begin{array}{r}5.5 \\
43.8 \\
38.2 \\
9.0 \\
2.1 \\
1.4\end{array}$ \\
\hline
\end{tabular}

Puerperal Breast Abscess-Time of Onset During Active Breast-feeding and after Weaning.-Complete information concerning breast-feeding was available in 129 mothers who developed breast abscess. Breast-feeding was never attempted in 13 of these, and in another 37 mothers the infant was weaned at varying intervals of time prior to the development of an abscess. Table $\mathrm{V}$ shows the time of onset of breast abscess after parturition in the remaining 79 mothers, who were actively breast-feeding when the abscess developed. It compares these with mothers who weaned their infants prior to the onset of breast abscess. This latter group of 50 mothers is further divided into two groups depending on whether the infant was fed and then weaned or was weaned at birth. Table $\mathrm{V}$ shows that the time of onset after parturition is virtually the same whether mothers actively breast-feed or wean their infants. Table VI shows the time of onset of breast abscess after weaning. The Table shows that a much shorter time interval after weaning occurred in the mothers who actively breast-fed their infants prior to weaning.

Puerperal Breast Abscess and Parity.-Table VII shows the proportion of primiparae and multiparae in normal confine-

TABLE V.-Comparison of Time of Onset of Breast Abscess After Parturition in Mothers Actively Feeding and Mothers who Weaned Infants at Birth

\begin{tabular}{|c|c|c|c|c|c|c|}
\hline \multirow{2}{*}{$\begin{array}{l}\text { Interval } \\
\text { after Par- } \\
\text { turition } \\
\text { (Days) }\end{array}$} & \multicolumn{2}{|c|}{$\begin{array}{l}\text { Infant Actively } \\
\text { Feeding }\end{array}$} & \multicolumn{2}{|c|}{$\begin{array}{l}\text { Infant Weaned } \\
\text { at Birth }\end{array}$} & \multicolumn{2}{|c|}{$\begin{array}{l}\text { Infant Actively } \\
\text { Fed Prior to } \\
\text { Weaning }\end{array}$} \\
\hline & $\begin{array}{l}\text { No. of } \\
\text { Mothers }\end{array}$ & $\%$ & $\begin{array}{l}\text { No. of } \\
\text { Mothers }\end{array}$ & $\%$ & $\begin{array}{l}\text { No. of } \\
\text { Mothers }\end{array}$ & $\%$ \\
\hline \multirow[t]{2}{*}{$\begin{array}{c}<14 \quad \ldots \\
14-28 \ldots \\
29-60 \ldots \\
60-120 \ldots \\
>120 \ldots\end{array}$} & $\begin{array}{r}7 \\
32 \\
31 \\
8 \\
1\end{array}$ & $\begin{array}{r}8.9 \\
40 \cdot 5 \\
39 \cdot 2 \\
10.1 \\
1.3\end{array}$ & $\begin{array}{l}-5 \\
5 \\
2 \\
1\end{array}$ & $\begin{array}{r}3 \overline{38 \cdot 5} \\
38 \cdot 5 \\
15 \cdot 4 \\
7 \cdot 6\end{array}$ & $\begin{array}{r}\overline{20} \\
14 \\
1 \\
2\end{array}$ & $\begin{array}{r}\overline{54 \cdot 1} \\
37 \cdot 8 \\
2 \cdot 7 \\
5 \cdot 4\end{array}$ \\
\hline & 79 & & 13 & & 37 & \\
\hline
\end{tabular}

TABLE VI.-Comparison of Time of Onset of Breast Abscess After Weaning in Mothers who Weaned Infants at Birth and in Mothers who Actively Fed Infants for Varying Periods of Time Prior to Weaning

\begin{tabular}{|c|c|c|c|c|c|c|c|}
\hline \multirow{2}{*}{\multicolumn{4}{|c|}{$\begin{array}{c}\text { Interval } \\
\text { after } \\
\text { Weaning } \\
\text { (Days) }\end{array}$}} & \multicolumn{2}{|c|}{$\begin{array}{l}\text { Infant Weaned } \\
\text { at Birth }\end{array}$} & \multicolumn{2}{|c|}{$\begin{array}{l}\text { Infant Actively Fed } \\
\text { Prior to Weaning }\end{array}$} \\
\hline & & & & $\begin{array}{l}\text { No. of } \\
\text { Mothers }\end{array}$ & $\%$ & $\begin{array}{l}\text { No. of } \\
\text { Mothers }\end{array}$ & $\%$ \\
\hline \multirow[t]{2}{*}{$\begin{array}{l}<14 \\
14-28 \\
20-60 \\
60-120 \\
>120 \\
\end{array}$} & $\begin{array}{l}\cdots \\
\because \\
\cdots \\
\end{array}$ & $\begin{array}{l}\cdots \\
\cdots \\
\cdots\end{array}$ & $\begin{array}{l}\because \\
\because \\
\ddot{x}\end{array}$ & $\begin{array}{l}-5 \\
5 \\
2 \\
1\end{array}$ & $\begin{array}{r}\overline{38 \cdot 5} \\
38 \cdot 5 \\
15 \cdot 4 \\
7 \cdot 6\end{array}$ & $\begin{array}{r}18 \\
8 \\
8 \\
2 \\
1\end{array}$ & $\begin{array}{r}48.6 \\
21 \cdot 6 \\
21 \cdot 6 \\
5.4 \\
2.8\end{array}$ \\
\hline & & & & 13 & & 37 & \\
\hline
\end{tabular}

ments and in the 142 mothers who developed breast abscess. The multiparae are further subdivided into two groups depending on the number of previous children. This table shows that breast abscess is relatively more frequent in primiparae than in multiparae and becomes relatively less frequent as parity increases.

TABLE VII.-Parity of 142 Mothers Developing Breast Abscess Compared with Parity of All Mothers Delivered in Geelong During 1957-62

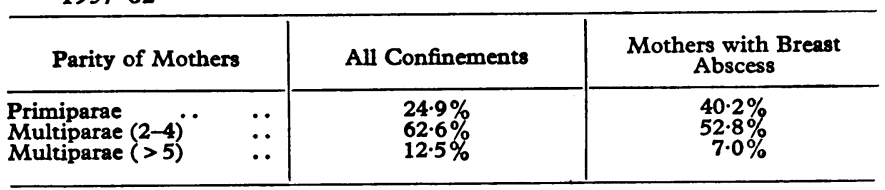

Breast-feeding-Incidence in Geelong during 1956-62.Table VIII shows the number and percentage of mothers breastfeeding their infants at varying times up to six months after delivery. It shows that there was no significant change in the breast-feeding habits of mothers in Geelong during 1956-62.

TABLB VIII.-Incidence of Breast-feeding in 10,635 Mothers Attending TABLE VIII Incidence of Breast-feeding in 10,635 Mothers

\begin{tabular}{|c|c|c|c|c|c|c|c|c|c|c|}
\hline \multirow{3}{*}{ Years } & & \multirow{3}{*}{$\begin{array}{c}\text { No. of } \\
\text { Mothers }\end{array}$} & \multicolumn{8}{|c|}{ Breast-Feeding } \\
\hline & & & \multicolumn{2}{|c|}{$\begin{array}{l}\text { From } \\
\text { Birth }\end{array}$} & \multicolumn{2}{|c|}{$\begin{array}{c}\text { At } 1 \\
\text { Month }\end{array}$} & \multicolumn{2}{|c|}{$\begin{array}{c}\text { At } 3 \\
\text { Months } \\
\end{array}$} & \multicolumn{2}{|c|}{$\begin{array}{c}\text { At } 6 \\
\text { Months } \\
\end{array}$} \\
\hline & & & No. & $\%$ & No. & $\%$ & No. & $\%$ & No. & $\%$ \\
\hline $\begin{array}{ll}1956-8 & \ldots \\
1959-60 & \cdots \\
1961-2 \quad & \cdots\end{array}$ & $\ddot{0}$ & $\begin{array}{l}3,797 \\
2,581 \\
4,257\end{array}$ & \begin{tabular}{|l|}
3,014 \\
1,896 \\
3,445
\end{tabular} & \begin{tabular}{|l|}
79 \\
73 \\
81
\end{tabular} & $\begin{array}{l}2,002 \\
1,217 \\
2,317\end{array}$ & $\begin{array}{l}52 \\
42 \\
54\end{array}$ & $\begin{array}{r}1,133 \\
624 \\
1,312\end{array}$ & $\begin{array}{l}30 \\
24 \\
31\end{array}$ & $\begin{array}{l}681 \\
358 \\
618\end{array}$ & $\begin{array}{l}18 \\
14 \\
15\end{array}$ \\
\hline
\end{tabular}

Nasal Staphylococcal Carrier Rate of Mothers and Normal Female Population.- Table IX shows the nasal carrier rate of coagulase-positive Staph. aureus during 1959-63 in various groups of mothers whose infants did and did not have antiseptic skin care. Nasal swabbings were taken on the fourth to seventh days of stay in hospital. The nasal carrier rate of the nonhospital normal female population of Geelong during the same period of time is also included.

TABLE IX.-Comparison of Nasal Carrier Rate of Coagulase-positive Staph. aureus in Various Groups of Women in Geelons During 1959-63

\begin{tabular}{|c|c|c|c|}
\hline & \multicolumn{3}{|c|}{ Nasal Carrier Rates } \\
\hline & 1959 & 1961-2 & 1963 \\
\hline 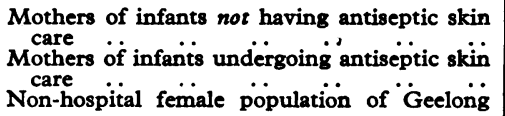 & $65 \%$ & $\begin{array}{l}55 \% \\
46 \% \\
34 \%\end{array}$ & $\begin{array}{l}46 \% \\
35 \%\end{array}$ \\
\hline
\end{tabular}

Bacterial Content of Human Breast Milk.-From July to December 1963 breast milk was collected from 87 mothers at varying times after delivery. The nipple area was washed and dried, using sterile water and cotton-wool swabs, and milk was then expressed into a sterile breast-pump prior to feeding the baby. The samples of milk collected were transferred aseptically to sterile screw-capped bottles packed in baskets containing freeze packs. Two samples of milk were collected from each breast. In five mothers further samples were taken during feeding and on completion of feeding. The breast milk collected was plated on to horse-blood-agar and into "salty" cooked meat medium and incubated at $37^{\circ} \mathrm{C}$. In addition three nutrient agar pourplates were made from $1 \mathrm{ml}$. of each sample of milk and of each dilution of 1/10,1/100, and 1/1,000 of milk in sterile water. All samples of milk were shaken by hand for two minutes before dilution and for 30 seconds between each dilution and culture. Total bacterial counts were made on the pour-plates showing between 30 and 300 colonies. Certain results of this study of the bacterial content of human breast milk are shown in Tables $\mathrm{X}$ and XI. Table $\mathrm{X}$ shows that breast 
milk is seldom sterile and often contains coagulase-positive Staph. aureus. By far the most common micro-organism isolated on culture was Staph. albus, which was grown from $87 \%$ of all breast milk cultured. Table XI shows that there was a great variation in the number of viable organisms in each millilitre of breast milk collected. This number tended to be lower as lactation was established. This is probably a dilution factor occurring with the greater flow of milk on full establishment of breast-feeding.

TABLE X.-Bacterial Flora Present in Breast Milk of 87 Mothers at Various Days up to 10 Days After Parturition. All Milk was Expressed Prior to Feeding Infant on the Day Sample was Taken

\begin{tabular}{|c|c|c|c|}
\hline Organism Grown on Culture & & No. of Mothers & $\begin{array}{l}\text { Percentage of } \\
\text { all Mothers }\end{array}$ \\
\hline 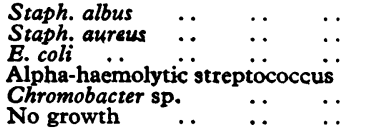 & $\begin{array}{l}\because \\
\because \\
\because \\
\because \\
\because\end{array}$ & $\begin{array}{r}76 \\
21 \\
3 \\
3 \\
2 \\
4\end{array}$ & $\begin{array}{l}87 \\
24 \\
3 \cdot 4 \\
3 \cdot 4 \\
2 \cdot 3 \\
4 \cdot 6\end{array}$ \\
\hline
\end{tabular}

TABLE XI.-Number of Staph. albus Organisms per ml. of Breast Milk at Varying Stages of the Puerperium

\begin{tabular}{|c|c|c|c|c|c|c|}
\hline & & & & Staph. & $\begin{array}{l}\text { No. of Viable } \\
\text { per ml. }\end{array}$ & $\begin{array}{l}\text { ganisms } \\
\text { ilk }\end{array}$ \\
\hline Breast-fe & edin & & Mothers & Grown & Variation & Average \\
\hline $\begin{array}{l}\text { Before ... } \\
\text { 1st day . d } \\
\text { 2nd-3rd day } \\
\text { 4th-6th day } \\
\text { 7th-10th day }\end{array}$ & $\begin{array}{l}\cdots \\
\cdots \\
\cdots\end{array}$ & $\begin{array}{l}\ldots \\
\cdots \\
\cdots\end{array}$ & $\begin{array}{r}4 \\
3 \\
18 \\
34 \\
28\end{array}$ & $\begin{array}{r}4 \\
3 \\
17 \\
29 \\
23\end{array}$ & $\begin{array}{r}7,800-34,000 \\
8,000-11,000 \\
650-102,000 \\
43-61,000 \\
260-49,000\end{array}$ & $\begin{array}{r}16,600 \\
9,800 \\
15,400 \\
17,500 \\
6,600\end{array}$ \\
\hline
\end{tabular}

Duration of Stay in Hospital after Parturition.-Table XII shows there has been only slight decrease in this since 1957. An abrupt decrease occurred late in 1956 following recommendations made by us (Plueckhahn and Banks, 1958).

TABLE XII.-Average Duration of Stay in Hospital of Puerperal Mothers During 1956-63. The Percentage of Mothers Discharged at Various Intervals Post Partum are Shown for Each Year

\begin{tabular}{c|c|c|c|c|c}
\hline \multirow{3}{*}{ Year } & \multicolumn{5}{|c}{ Days in Hospital after Parturition } \\
\cline { 2 - 6 } & 5 or Less & 6 and 7 & 8 and 9 & 10 and 11 & 12 or More \\
\hline 1956 & $1 \cdot 7$ & 4.7 & 31.0 & 39.6 & 23.0 \\
1957 & 2.8 & 27.2 & 41.2 & 18.4 & 10.4 \\
1958 & 2.3 & 29.0 & 37.2 & 18.4 & 13.1 \\
1959 & 2.3 & 27.7 & 38.2 & 20.3 & 11.5 \\
1960 & 3.3 & 35.6 & 36.2 & 13.7 & 11.2 \\
1961 & $5 \cdot 2$ & 38.1 & 38.0 & 10.7 & 8.0 \\
1962 & 4.8 & 38.2 & 34.0 & 12.7 & 10.3 \\
1963 & 3.7 & 39.3 & 34.9 & 13.7 & 8.4 \\
\hline
\end{tabular}

\section{Discussion}

Staphylococcal disease in puerperal mothers usually occurs as acute mastitis, which may or may not be followed by abscess formation. The bacterial agent responsible for puerperal breast abscess is almost invariably the staphylococcus (Table I).

Compared with the numerous extensive surveys concerning staphylococcal disease in newborn infants, there is a comparative lack of information concerning their mothers and the occurrence of puerperal breast abscess. This is largely due to difficulty in follow-up investigations at home, for the onset of puerperal mastitis occurs usually after the mothers have been discharged from hospital in an apparently normal puerperium (Table IV).

Many reports relating to the incidence of acute mastitis after parturition are probably misleading and are on the side of underestimation. Other reports are not clear as to the exact criterion adopted concerning what constituted mastitis and are on the side of overestimation when simple painful breast engorgement is included. In view of these factors markedly different incidences of acute mastitis and breast abscess have been reported over the past 100 years.
In the latter half of the nineteenth century there was an incidence of between $5.9 \%$ and $13 \%$ "mastitis puerperalis" in mothers after delivery in Dresden and Basle (Dietrick and Frangenheim, 1926). With the advent of the antiseptic and aseptic eras there was an apparent decrease in the frequency of mastitis, and Möbius (1950) reported an incidence of $1.6 \%$ breast abscess during 1936-48.

A thorough survey of " puerperal and lactational mastitis" was carried out by Fulton (1945) in Dundee, Scotland, from October 1941 to December 1943. "Mastitis" was considered to be present only where there was spontaneous evacuation or incision of an abscess. In 748 hospital deliveries there was an incidence of $16.2 \%$ breast abscess compared with $3.5 \%$ in the 1,003 mothers delivered at home. This survey was very carefully conducted, but Fulton still stated, " almost certainly some cases were missed, but any inaccuracy must have been on the side of underestimation."

A much higher incidence of breast abscess in hospital deliveries when compared with home deliveries is also reported by others (Moon and Gilbert, 1935 ; Noack, 1955), although Knight and Nolan (1959) found similar proportions in 1957, when there was an incidence of $2.8 \%$ breast abscess in home deliveries and $3.1 \%$ in hospital confinements in Edinburgh. Similarly, Semple (1960), in his annual report as Medical Officer of Health for Liverpool for 1958, gave details of a survey of over 7,000 mothers and found the incidence of breast abscess was almost the same in deliveries taking place in hospital $(2.5 \%$ incidence of breast abscess) and at home ( $2.6 \%$ incidence of breast abscess).

In the past 20 years there have been many reports of outbreaks of puerperal breast abscess assuming epidemic proportions. Gibberd (1953) reported an incidence of $50 \%$ of mothers in one such epidemic. Most of the reports are linked with a previous or concurrent increase in staphylococcal disease in the infants delivered in the same maternity hospital (Knott and Blaikley, 1944 ; Pyle, 1948 ; Colbeck, 1949 ; Webb, 1954 ; Sherman, 1956 ; Ravenholt et al., 1957 ; Wysham et al., 1957). The mechanisms of infection of mothers during "epidemics" of puerperal breast abscess is probably different from that in the "endemically" occurring breast abscess following parturition, which is regarded as an uncommon but almost normal hazard of pregnancy. Colbeck (1962) thinks there is an almost irreducible minimum of breast abscess of approximately $0.5 \%$ of women delivered.

The endemic breast abscess may occur quite independently of the newborn infant, and in the present survey 13 mothers who never put their babies to the breast developed such an abscess (Table V). Another two women developed breast abscess prior to parturition (Table I).

Irrespective of the type of breast abscess or the exact mechanisms involved there is no doubt that a decrease in morbidity of the newborn from staphylococcal disease is accompanied by a decrease in the incidence of breast abscess occurring

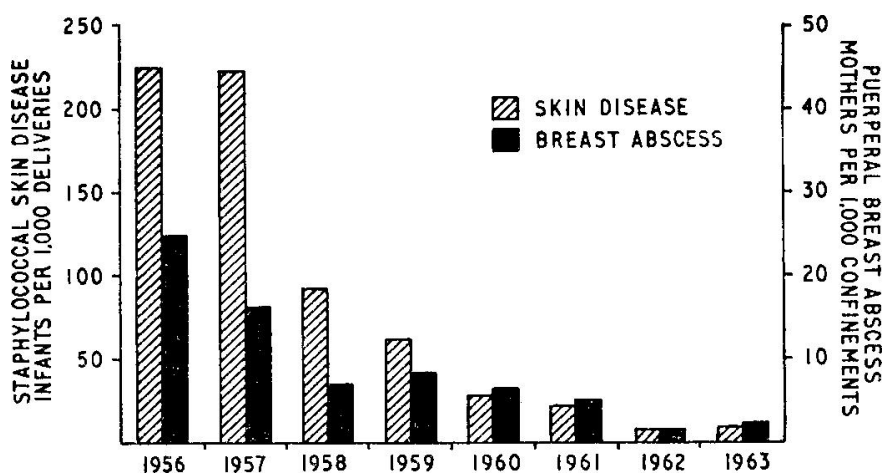

Yearly incidence of staphylococcal skin disease in infants and of puerperal breast abscess in mothers. The marked parallel drop in incidence of these conditions is clearly shown. 
in the mothers (Corner et al., 1960 ; Simpson et al., 1960 ; Hill, 1964). This decrease is strikingly shown in the accompanying Chart drawn from Table II.

Many changes in the conduct of the maternity wing were made during October 1956 to May 1957 but virtually no changes in the nursing care of mothers occurred after this period. The various measures, such as rooming-in and antiseptic skin care of the newborn, adopted during 1958 to 1963 were directed to lessening the incidence of staphylococcal disease in the baby itself (Plueckhahn, 1961 ; Plueckhahn and Banks, 1963). The birth rate, average age, parity, economic status, and breast-feeding habits of mothers delivered in Geelong all remained virtually the same during the seven and a half years covered in our survey (Table VIII). The duration of postpartum stay in hospital of mothers decreased (Table XII). There was an abrupt decrease after our recommendations late in 1956 (Plueckhahn and Banks, 1958). Table XII shows that since then the variation in the duration of stay in hospital has been very slight.

Table III shows the incidence of breast abscess occurring in two groups of mothers nursed identically except for antiseptic skin care in infants from one group. The marked decrease in maternal morbidity due to breast abscess where infants were undergoing antiseptic skin care with Phisohex is strikingly shown. This reduction has been maintained for four years (Table III).

Many factors may play a part in the morbidity of both mothers and infants. Valentin (1960) showed a marked decrease in the incidence of "purulent infection of the newborn" when infants underwent no change in nursing technique but mothers and nursing staff washed their hands with Phisohex before feeding infants or expressing milk. The incidence of puerperal mastitis dropped from $5.9 \%$ in 1953 to $1.5 \%$ during the years 1958 and 1959, when these measures were adopted, and with this there was a corresponding reduction in staphylococcal infection in the infants.

The occurrence of staphylococcal disease after transfer of staphylococci to a new site depends on many factors, which include the number of viable organisms transferred, conditions aiding their local and general multiplication, the susceptibility of the recipient host tissue, and the virulence of the strain of staphylococcus.

Puerperal breast abscess is almost invariably caused by the ubiquitous staphylococcus (Table I), and mothers are fortunate that the circumstances of the infection generally play a more important part in the establishment of staphylococcal disease than factors directly related to the organism itself. Occasionally the latter assume greater importance, and then outbreaks of breast abscess may assume epidemic proportions. In one such outbreak $15 \%$ of mothers developed breast abscess predominantly due to a staphylococcus of unusual phage type (Colbeck, 1949). The same staphylococcus (phage type 57) was also present in the nasopharynx and lesions of many babies. Similarly, Ravenholt et al. (1957) reported an epidemic in Seattle, where $19.4 \%$ of mothers developed breast abscess and $35 \%$ of their infants developed pyoderma mainly due to staphylococci, of the then uncommon phage type $42 \mathrm{~B} / 81$.

At no stage have "epidemics" occurred in the present survey, but $63.6 \%$ of the staphylococci isolated on culture from breast abscesses have been of phage pattern $80 / 81$. This percentage of phage pattern $80 / 81$ is much higher than that occurring in the maternity wing generally, where $13.5 \%$ of staphylococci isolated in "carrier rate" surveys and $8.7 \%$ isolated from lesions in the newborn were of this phage pattern (Plueckhahn, 1961).

It would appear that "virulence" of a particular strain plays a greater part in staphylococcal disease in the mother than in the infant.

Even with a "virulent" strain the size of bacterial invasion required to constantly produce staphylococcal disease is large
(Elek, 1956 ; Elek and Conen, 1957). The size of the bacterial invasion depends both on the number of organisms transferred and on the local and general conditions aiding their multiplication at the new site. Undoubtedly any measure reducing the number of staphylococci in a maternity hospital will be reflected by a decreased incidence of staphylococcal disease in infants and mothers. This survey shows that a highly effective measure is antiseptic skin care of the newborn infant with a $3 \%$ hexachlorophane emulsion (Chart, Tables II and III). A concomitant of this measure was a reduction in staphylococcal colonization of the nasopharynx of both infants (Plueckhahn and Banks, 1961) and mothers (Table IX).

Local factors related to breast-feeding itself may be a precipitating cause in the aetiology of breast abscess. Such local factors include cracked and inflamed nipples, poor breast hygiene, and blocked lactiferous ducts.

Under " normal" conditions breast milk almost invariably contains numerous viable organisms (Table $\mathrm{X}$ ). The bacterial count tends to fall with the onset of lactation and free flow of milk (Table XI). Any obstruction to the flow of milk will cause stasis, with a resultant local increase in the bacterial count and an increased liability for clinical infection. Active breastfeeding is not necessary for the occurrence of puerperal breast abscess, and $9.9 \%$ occurred in mothers who had never suckled their infants (Table V). In these mothers upsets in involution of the breast probably occasioned cystic change in ducts and acini, with retention of colostrum and milk. Similar upsets may occur in the breasts of both male and female newborn infants as a result of hormonal stimulation received in utero (Table I). The onset of the five breast abscesses seen in newborn infants occurred from two to four weeks after delivery.

The average time of onset of breast abscess is about the fourth week after parturition. This interval of time does not materially differ whether mothers are actively breast-feeding or have weaned their infants (Table V). The time of onset following weaning does vary significantly, depending on whether the infants were suckled prior to being weaned (Table VI). Inquiry showed that most mothers who weaned infants during active breast-feeding did so because of "cracked," "tender," or "inflamed" nipples. In these mothers it is the circumstances surrounding the weaning and not the actual process of weaning which precipitated the occurrence of breast abscess.

Many factors other than those discussed may play a part in the occurrence of "endemic" and "epidemic" breast abscess after parturition. Similarly, there are approaches, other than antiseptic skin care of infants, to the control of staphylococcal infection in mothers following parturition.

This survey shows that one very effective approach to the control of puerperal breast abscess is by the control of staphylococcal infection in infants by means of antiseptic skin care with a $3 \%$ hexachlorophane emulsion.

\section{Summary}

An extensive survey of the occurrence of breast abscess in 18,275 women delivered in the maternity wing of the Geelong and District Hospital from July 1956 to December 1963 is presented. The survey includes a thorough followup investigation of these mothers for a period of six months after parturition.

A reduction in the incidence of puerperal breast abscess from $2.5 \%$ to $0.16 \%$ of mothers is reported and the factors responsible are discussed. A correlation between breast abscess in mothers and staphylococcal skin disease in infants is shown.

There is evidence that "virulence" of a particular strain of staphylococcus probably plays a greater part in staphylococcal disease in the mother than in the infant. 
Antiseptic skin care of infants with a $3 \%$ hexachlorophane emulsion is shown to be a very effective method of reducing puerperal breast abscess in mothers.

\section{REFERENCES}

Colbeck, J. C. (1949). Canad. med. Ass. f., 61, 557.

(1962). Control of Infections in Hospitals. Hospital Monograph Series, No. 12, p. 54. American Hospital Association, Chicago. Corner, B. D., Crowther, S. T., and Eades, S. M. (1960). Brit. med. F., 1, 1927.

Dietrick, A., and Frangenheim, P. (1926). Neue Dtsch. Chir., 35, 74.

Elek, S. D. (1956). Ann. N.Y. Acad. Sci., 65, 85.

F and Conen, P. E. (1957). Brit. 7. exp. Path., 38, 573.

Fulton, A. A. (1945). Brit. med. F., 1, 693.

Gibberd G. F (1953) Amer. \% Obstec. Gymec., 65, 1038.

Hill, A. M. (1964). Med. F. Aust., 1, 101.

Knight, I. C. S., and Nolan, B. (1959). Brit. med. F., 1, 1224

Knott, F. A., and Blaikley, J. B. (1944). F. Obstet. Gynaec. Brit. Emp. 51, 386.
Möbius, W. (1950). Dtsch. Gesundh.-Wes., 5, 423. Cited by Valentin (1960).

Moon, A. A., and Gilbert, B. (1935). 7. Obstet. Gynaec. Brit. Emp., 42, 268.

Noack, H. (1955). Geburtsh. u. Frauenheilk., 15, 224

Plueckhahn, V. D. (1961). Brit. med. F., 2, 779.

Pluecknd Banks, (1958). Med. F. Aust., 1, 664.

- and Banks, J. (1958). Med. F. Aust., 1, 664.

(1963). Med. F. Aust., 2, 519.

Pyle, L. R. (1948). Amer. F. Obstet. Gynec., 55, 676

Ravenholt, R. T., Wright, P., and Mulhern, M. (1957). New Engl. Y. Med., 257, 789.

Semple, A. B. (1960). Practitioner, 185, 383.

Sherman, A. J. (1956). Obstet. and Gynec., $7,268$.

Simpson, K., Tozer, R. C., and Gillespie, W. A. (1960). Brit. med. Y., 1,315 .

Valentin, H. (1960). Med. Welt (Stuttg.), 2, 121.

Webb, J. F. (1954). Canad. med. Ass. F., 70, 382

Wysham, D. N., Mulhern, M. E., Navarre, G. C., La Veck, G. D., Kennan, A. L., and Giedt, W.' R. (1957). New Engl. J. Med., 257, 304.

\title{
Further Observations on Vaccination in Infancy with Oral Poliomyelitis Vaccine and Diphtheria, Tetanus, Pertussis Vaccine
}

\author{
N. R. BUTLER,* M.D., M.R.C.P., D.C.H. ; P. F. BENSON, † M.B., M.R.C.P., D.C.H. ; \\ J. URQUHART, $\ddagger$ M.B., CH.B., D.P.H. ; A. P. GOFFE, $§$ M.B., DIP.BACT. ; \\ G. J. KNIGHT,§ F.I.S. ; T. M. POLLOCK, $\|$ M.B., СH.B.
}

Brit. med. F., 1964, 2, 418-420

The scheme generally employed at present in Britain for infant immunization requires six visits to the clinic within the first 18 months of life. Three injections of combined diphtheria, tetanus, and pertussis vaccine (triple vaccine) are followed by three doses of oral trivalent poliomyelitis vaccine. By giving the poliomyelitis vaccine concurrently with the triple vaccine the number of visits is reduced to three, and this procedure has been shown to be effective even in very young infants, using a dose of $10^{6}$ of each virus type (Benson et al., 1963). Two further studies have now been made along similar lines, one using smaller doses and the other fewer doses of poliomyelitis vaccine.

\section{Procedure}

The participants were healthy infants attending for routine primary immunization at the infant welfare clinics. Pre-vaccination serum samples were obtained from all infants immediately before their first dose of vaccine. The triple vaccine and the poliomyelitis vaccine (Sabin) were prepared at the Wellcome Research Laboratories. The dose of poliomyelitis vaccine was contained in three drops given directly into the mouth from a dropper bottle, and the triple vaccine was injected subcutaneously. The interval between doses was four weeks. There were two main studies.

Study 1 was designed to assess the efficacy of three doses of $10^{5.5} \mathrm{TCD}_{50}$ of each virus type (group A). While this study was in progress at the University College Hospital, London, the Ministry of Health recommended that the schedule of poliomyelitis vaccination should be three doses of trivalent vaccine,

\footnotetext{
* Immunization Clinic, University College Hospital, London. Present address : Hospital for Sick Children, Great Ormond Street, London. Paediatric Research Unit, Guy's Hospital Medical School, London. $¥$ Medical Officer of Health, Borough of Swindon, Wiltshire. The Wellcome Research Laboratories, Beckenham. If Medical Research Department, the Wellcome Foundation.
}

each dose consisting of $10^{5.7}$ type $1,10^{5}$ type 2 , and $10^{5.5}$ type 3. A second group of children (group B) at University College Hospital and Swindon Public Health Department were accordingly vaccinated by this regime. Study 1 thus consisted of an assessment of each of the above schedules independently, and it was not designed as a comparison of the relative efficacy of the two schedules. In both groups a postvaccination serum sample was taken four weeks after the final dose ; antibody estimations were made in parallel from the preand post-vaccination sample.

In Study 2, made at Salomons' Centre, Guy's Hospital, the infants were placed in three groups according to a table of random numbers. The infants in the first group were given one dose of trivalent poliomyelitis vaccine, in the second group two doses, and in the third group three doses. Post-vaccination serum samples for each group were obtained four weeks after the final dose. Each dose contained $10^{5.7}$ type 1, $10^{5}$ type 2, and $10^{5.5}$ type 3 .

\section{Results in Study 1}

Sixty-three infants were immunized in group A; 29 of these infants were aged 5 to 12 weeks of age; all but two of the remainder were 13 to 28 weeks. There were 58 infants in group B ; eight of these were aged 9 to 12 weeks, the remainder were 13 to 32 weeks (Table I). Group A thus contained a larger proportion of infants who were less than 3 months old than group $B$.

TABLE I.-Age Distribution of Infants in Study 1

\begin{tabular}{r|c|c|c|c|c|c|c|c|c}
\hline Age in weeks: & $5-8$ & $9-12$ & $13-16$ & $17-20$ & $21-24$ & $25-28$ & $29-32$ & $33-36$ & $37-40$ \\
\hline $\begin{array}{r}\text { No. of infants: } \\
\text { Group A (63) } \\
\text { B (58) }\end{array}$ & - & 23 & 19 & 8 & 2 & 3 & - & 1 & 1 \\
\hline
\end{tabular}

